2003s-30

\title{
Advertising Restrictions and Competition in the Children's Breakfast Cereal Industry
}

\author{
C. Robert Clark
}

\begin{tabular}{c}
\hline Série Scientifique \\
Scientific Series
\end{tabular}

Montréal
Mai 2003

(C) 2003 C. Robert Clark. Tous droits réservés. All rights reserved. Reproduction partielle permise avec citation du document source, incluant la notice (C).

Short sections may be quoted without explicit permission, if full credit, including (C) notice, is given to the source.
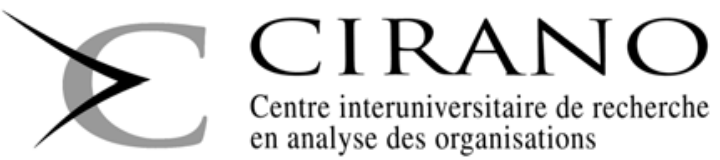

Centre interuniversitaire de recherche

en analyse des organisations 


\section{CIRANO}

Le CIRANO est un organisme sans but lucratif constitué en vertu de la Loi des compagnies du Québec. Le financement de son infrastructure et de ses activités de recherche provient des cotisations de ses organisationsmembres, d'une subvention d'infrastructure du ministère de la Recherche, de la Science et de la Technologie, de même que des subventions et mandats obtenus par ses équipes de recherche.

CIRANO is a private non-profit organization incorporated under the Québec Companies Act. Its infrastructure and research activities are funded through fees paid by member organizations, an infrastructure grant from the Ministère de la Recherche, de la Science et de la Technologie, and grants and research mandates obtained by its research teams.

Les organisations-partenaires / The Partner Organizations

PARTENAIRE MAJEUR

. Ministère du développement économique et régional [MDER]

PARTENAIRES

. Alcan inc.

. Axa Canada

. Banque du Canada

. Banque Laurentienne du Canada

. Banque Nationale du Canada

. Banque Royale du Canada

. Bell Canada

. Bombardier

. Bourse de Montréal

. Développement des ressources humaines Canada [DRHC]

. Fédération des caisses Desjardins du Québec

. Gaz Métropolitain

. Hydro-Québec

. Industrie Canada

. Ministère des Finances [MF]

. Pratt \& Whitney Canada Inc.

. Raymond Chabot Grant Thornton

. Ville de Montréal

. École Polytechnique de Montréal

. HEC Montréal

. Université Concordia

. Université de Montréal

. Université du Québec à Montréal

. Université Laval

. Université McGill

Associé AU :

. Institut de Finance Mathématique de Montréal (IFM²)

. Laboratoires universitaires Bell Canada

. Réseau de calcul et de modélisation mathématique $\left[\mathrm{RCM}^{2}\right]$

. Réseau de centres d'excellence MITACS (Les mathématiques des technologies de l'information et des systèmes complexes)

Les cahiers de la série scientifique (CS) visent à rendre accessibles des résultats de recherche effectuée au CIRANO afin de susciter échanges et commentaires. Ces cahiers sont écrits dans le style des publications scientifiques. Les idées et les opinions émises sont sous l'unique responsabilité des auteurs et ne représentent pas nécessairement les positions du CIRANO ou de ses partenaires.

This paper presents research carried out at CIRANO and aims at encouraging discussion and comment. The observations and viewpoints expressed are the sole responsibility of the authors. They do not necessarily represent positions of CIRANO or its partners.

ISSN 1198-8177 


\title{
Advertising Restrictions and Competition in the Children's Breakfast Cereal Industry*
}

\author{
C. Robert Clark
}

\begin{abstract}
Résumé / Abstract
Nous prenons avantage de l'interdiction de diffuser de la publicité à l'intention des enfants au Québec pour étudier l'effet de la publicité dans l'industrie des céréales. La publicité est considérée comme étant anti-concurrentielle si elle augmente la loyauté envers la marque, alors qu'elle est vue comme étant bénéfique pour la concurrence si elle agit comme un substitut à la reconnaissance de la marque. Nous construisons un modèle de marques établies et non-établies sur le marché où la publicité a pour but d'informer les consommateurs sur l'existence des marques. Le modèle prédit que toute prohibition de la publicité a pour conséquence de permettre aux marques établies d'augmenter leur part de marché au détriment de celles qui sont nouvelles et moins connues. Ce résultat est validé par les données. En effet, les marques les plus anciennes et les mieux connues ont des parts de marché plus élevées au Québec que dans les régions où la publicité est permise. L'inverse est vrai pour les marques nonétablies. Notre résultat suggère que dans ce marché, la publicité ne peut pas augmenter la différentiation de produit et réduire la concurrence.
\end{abstract}

Mots clés : réglementation de la publicité, concurrence, marques établies.

This paper takes advantage of the ban on advertising directed at children in the province of Quebec to study the effect of advertising in the children's breakfast cereal industry. Advertising is viewed alternatively as anti-competitive, if it increases brand loyalty, or as pro-competitive, if it acts a substitute for brand recognition. I construct a model of established and non-established brands in which advertising serves to inform consumers about the existence of brands. The model predicts that the effect of prohibiting advertising is to permit established brands to enjoy greater market share at the expense of newer and less well-known brands. This prediction is supported by the data: older, better-known brands have higher market share in Quebec than in regions where advertising is permitted and the opposite is true for non-established brands. This result suggests that in this market the effect of advertising cannot be to increase perceived product differentiation and reduce competition.

Keywords: advertising restrictions, market concentration, established brands.

Codes JEL : L0, L1, M3

\footnotetext{
* I would like to thank Ig Horstmann, Todd Stinebrickner, Arthur Robson, Srihari Govindan, Audra Bowlus, Pierre-Thomas Léger, Benoit Dostie, Désiré Vencatachellum, and Mara Berman for helpful comments. I greatly appreciate the assistance that Sridhar Moorthy and Sean Forbes of the Rotman School of Management gave me in procuring the data used in this project. I am grateful to Frank Mathewson and the Institute for Policy Analysis for their support and hospitality.

$\dagger$ Institute of Applied Economics, HEC Montreal, Université de Montréal, 3000 Côte-Sainte-Catherine, Montréal, Québec, Canada, H3T 2A7 and CIRANO; Email: Robert.Clark@hec.ca.
} 


\section{INTRODUCTION}

Over the past twenty-five years there has been a growing concern over the effect of advertising on children. This concern has led countries throughout the world to enact, or consider enacting, legislation prohibiting advertising directed at children. Through its Radio and Television Act, Sweden has banned the practice of marketing to children under the age of 12 on television and radio and does not allow any advertising immediately before or after children's programming (Advertising Education Forum). Greece, meanwhile, has banned toy advertising. In the United States, concern over the effects of advertising has led Senator Hillary Clinton to state the she would like to put an end to "unfair" marketing to children (Christopher BrownHumes, Financial Times, January 2001).

In Canada, the Quebec Consumer Protection Act has outlawed commercial advertising directed at persons under the age of thirteen. This legislation came into being in April of 1980. From that point forward, advertising directed at children was prohibited under sections 248 and 249 of the Act. Three issues must be considered in order to determine whether an advertisement is directed at children: i) the nature and intended purpose of the goods advertised, ii) the manner of presenting the advertisement and iii) the time and place it is shown. If products are intended exclusively for the use of children or have a marked appeal for children, then they cannot be advertised at all on children's programmes, and can only be advertised on other programmes if they are treated so as not to appeal to the needs of children.

Reducing the consumption by children of various products is clearly the main purpose of these advertising restrictions. A comparison of consumption patterns for children's products before and after a ban would provide a proper gauge of the success of the legislation. Unfortunately, in the case of the Quebec prohibition, this 
is not possible as data going back to the 1970's are not easily accessible. However, data collected by the Print Measurement Bureau of Canada (described in further detail below) allow for an across province comparison and show that, at least in the case of sweetened cereals and video game systems, the advertising restrictions may not have had the hoped for results. The proportion of households that reported purchasing sweetened cereals or owning video game systems that connect to the television in Quebec is the same as the proportion in the rest of Canada (in 2002, $26 \%$ for sweetened cereals and $27 \%$ for video game systems). ${ }^{1}$

In addition, the legislation may have had the unintended consequence of reducing competition in markets for children's products. Two broad views of the effect of advertising exist in the literature. Advertising is viewed alternatively as increasing or reducing perceived brand differentiation. If advertising increases brand loyalty, it generates the perception that there are fewer substitutes for advertised brands, and therefore increases perceived differentiation. As such this view holds advertising to be anti-competitive. On the other hand, if advertising inspires consumers to try brands that they know less well, it increases the number of available substitutes and therefore reduces perceived product differentiation. According to this procompetitive view, advertising acts as a substitute for brand experience and brand recognition. If advertising is anti-competitive, restricting it should reduce the market shares of older, better-known brands that have used advertising to develop loyal followings, and may allow new brands access to the market. If advertising is pro-competitive, an advertising ban could potentially help older, more recogniz-

\footnotetext{
${ }^{1}$ In the case of sweetened cereals it is possible that prior to the ban a larger proportion of households in Quebec purchased presweetened cereals and that $26 \%$ represents a significant decrease. This argument seems far less likely in the case of video game systems which were not in wide-spread use before the ban.
} 
able brands. $^{2} \quad$ Without the ability to advertise, new brands may not succeed in penetrating the market.

Based on the premise that advertising can substitute for brand recognition, I construct a model in which there are two types of brands-established and nonestablished. Established brands differ from non-established brands in that in the absence of advertising some consumers may still recognize established brands. This is because older brands have had the opportunity to develop a reputation through heavy promotional activity. I assume that the only role for advertising in this model is to inform consumers that are not aware of a brand of its existence. So advertising acts as a substitute for recognition by informing consumers about existence. ${ }^{3}$ The model predicts that established brands should have greater market share in regions where advertising is prohibited than in regions where it is allowed and the opposite is true for non-established brands. These predictions lend support to the view that advertising is pro-competitive. Without the ability to advertise, less established brands are unable to provide information about their existence and characteristics to consumers.

I then test these predictions by examining the children's breakfast cereal market in Canada. Ready-to-eat cereals are among the most advertised children's products in Canada (Caron (1995)). I use a unique data set from the Print Measurement Bureau of Canada which surveys the purchasing behaviour of some fifteen thousand Canadian households annually as well as advertising data from AC Nielsen to confirm the predictions of my model. Brands that have been around longer and that regularly

\footnotetext{
${ }^{2}$ If scale economies in advertising exist or if advertising leads to economies of scope in manufacturing by widening markets, then, even if advertising is pro-competitive, leading firms may be hurt by an advertising ban. So predictions about the overall effect of advertising restrictions under the pro-competitive theory are not straight-forward.

${ }^{3}$ Alternatively, a brand could be established if it provides consumers with some extra utility through image or prestige effects. In this case persuasive advertising could act as a substitute.
} 
engage in promotion have higher market share in Quebec than in Canadian regions where advertising is permitted, and the opposite is true for non-established brands.

Similar results on the effect of advertising restrictions on competition in different industries have been reported. Eckard (1991) studies the cigarette industry through an examination of the 1971 ban on television advertising in the United States. By comparing measures of competition in the cigarette industry in the ten years prior to the ban and in the ten years after, he finds that shares of leading brands were declining before the ban on advertising, but stable or increasing after its imposition. He also finds that the ban impedes the entry of new firms into the industry. Holak and Reddy (1986) report similar results. They find that the effect of past sales on current purchases is stronger after the ban on cigarette advertising. The only study that examines restrictions that vary by region is Sass and Saurman (1995). They study the malt beverages industry and find that advertising restrictions lead to increases in market concentration.

An important difference between the present study and those mentioned above is that I explicitly model the mechanism through which established firms gain market power when advertising is banned. Established brands are recognized in the absence of advertising. Less established brands are hurt by the ban since they cannot inform consumers of their existence. Holak and Reddy, Eckard, and Sass and Saurman all focus on the effect of advertising restrictions on big market-share brands. They do not model what it is about having a large market share that allows these brands to grow in the absence of advertising. Holak and Reddy do point out that there is some evidence that being an early entrant could be important. They show for some cigarette categories that purchase inertia for earlier entrants is greater after the ban. Sass and Saurman discuss what it is about big-share brands that allows them to enjoy greater market share in states where advertising is restricted: 
big-share brands are produced by large national brewers, while small-share brands are produced by local brewers. But since these two sets of brewers have very different marketing capabilities, it is not surprising that the local brewers are at a disadvantage where advertising is restricted. The national brewers are barely affected by state restrictions since their marketing campaigns tend to be national. So the local brewers are the only ones that are really hurt by the ban. In my study all brands are marketed and sold nationally. My results suggest that brands that are similarly affected by the advertising prohibition may still enjoy different levels of market power depending on whether or not they are established.

The results presented here are also consistent with previous work on the breakfast cereal industry. Shum (2000) looks at the breakfast cereal industry to determine whether advertising increases or decreases brand loyalty. Consumers that are loyal to a particular brand will perceive fewer substitutes for it. He shows that the breakfast cereal market is characterized by considerable brand loyalty and that a brand's advertising has a bigger impact on consumers that are not loyal to it- in other words advertising helps to overcome brand loyalty.

The remainder of the paper proceeds as follows. In the next section I develop the theoretical model of informative advertising and describe its predictions. Section 3 describes the data. Section 4 outlines the empirical specification and section 5 contains results. Section 6 concludes. Tables containing regression results, a list of children's brands, and summary statistics are in the appendix. 


\section{A Model of Informative Advertising and Brand Awareness}

I construct a simple discrete-choice model in which brand recognition plays a role. The market is populated by a continuum of risk neutral households of mass 1 . A household is composed of a child and a parent who acts as an agent of the child. Each household purchases at most one unit of one of the $j=1 \ldots J$ varieties. The indirect utility for a household $i$ from consuming variety $j$ is $u_{i j}=v_{j}-p_{j}+\varepsilon_{i j}$. The parameter $v_{j}$ represents the systematic value that each household gets from consuming brand $j$, while $p_{j}$ is the price they pay for it. $\varepsilon_{i j}$ is household $i$ 's idiosyncratic valuation for the $j$ th brand.

An outside alternative must also be specified. This is representative of the option of not buying any of the available brands of children's cereals. The utility of the no-purchase alternative is normalized to zero.

I can then determine the discrete choice market shares in the standard way. Each household purchases one unit of the variety that yields them the highest utility. Conditional on valuations $v_{.}=\left(v_{1}, \ldots, v_{J}\right)$ and prices $p .=\left(p_{1}, \ldots, p_{J}\right)$, a household $i$ purchases one unit of brand $j$, if and only if, for every $l \geq 0$ and $l \neq j, u_{i j}=$ $v_{j}-p_{j}+\varepsilon_{i j} \geq u_{i l}=v_{l}-p_{l}+\varepsilon_{i l}$. I can then define the set of unobservables, $\varepsilon_{i .}=\left(\varepsilon_{i 1}, \ldots, \varepsilon_{i J}\right)$ that induces the choice of brand $j$ :

$$
A_{j}\left(v_{.}, p .\right)=\left\{\varepsilon_{i .} \mid u_{i j} \geq u_{i l}, \forall l \neq j\right\}
$$

If ties occur with zero probability, the market share of brand $j$ as a function of the characteristics of all the brands competing in the market is given by the probability that $\varepsilon_{i}$ falls into the region defined by $A_{j}$ :

$$
S_{j}(v ., p .)=\int_{A_{j}} d F^{*}(\varepsilon)
$$


The integral is over the set of consumer unobservables defined by $A_{j}$ and $F^{*}$ is the distribution of these unobservables in the population.

I assume that the $\varepsilon_{i j}$ are distributed according to a Type I extreme-value distribution, so the market share of brand $j$ can be written as:

$$
S_{j}=\frac{\exp \left(v_{j}-p_{j}\right)}{1+\sum_{h=1}^{J} \exp \left(v_{h}-p_{h}\right)}
$$

Firms have access to a single advertising technology. This technology communicates a message that any given household might either "see" or "not see". The message cannot be targeted at specific households (i.e., the firm cannot control which children hear the message and which do not) and the probability that any given household hears a message is the same for all households. ${ }^{4}$ These assumptions mean that I can define an advertising rate for brand $j$ by a scalar $a_{j} \in[0,1]$ denoting both the fraction of the population that hears a message for brand $j$ and the probability that any given consumer hears this message.

If the firm advertises, it incurs a variable cost, $c(a)$, should it advertise at rate $a$. I assume that $c(0)=0$ and that $c(\cdot)$ is increasing and strictly convex. Costs are normalized such that $c^{\prime}(0)=0$. Advertising costs are the same for all firms. Firms also incur a constant unit production cost which is normalized to zero. Firms are risk neutral and each chooses a price and an advertising rate to maximize expected profits.

I assume that the only role for advertising in this model is to inform households of a brand's existence. So advertising acts as a substitute for recognition by informing households about existence. ${ }^{5}$ In the absence of advertising, households may be still be aware of brands. I assume that a fraction $g_{j} \in(0,1)$ of households 'have heard

\footnotetext{
${ }^{4}$ What is being abstraced from here is any notion of the quality of an ad campaign.

${ }^{5}$ As mentioned above, persuasive advertising could act as a substitute if being established provides consumers with some extra utility through image or prestige effects.
} 
of' brand $j$. This may be because the brand was advertised in the past or because households pass on information through word of mouth. I suppose that there are two types of children's breakfast cereal brands: established children's brands, $e$, and non-established brands, $n$, that number $N_{e}$ and $N_{n}$ respectively. Established brands and non-established brands differ in the fraction of households that have heard of them in the absence of advertising. The normalization I am going to adopt here is that the fraction of households that have heard of a non-established brand $n, g_{n}$, is equal to zero. That is, in the absence of advertising, no household is aware of a non-established brand.

The timing of moves in the model is as follows: The firms simultaneously choose prices and advertising rates. A fraction $a_{j}$ of households hear a message from firm $j$. Brands about which household $i$ is aware (either through advertising or because they are established) become part of their "consideration set". They chooses the best available option from this set.

\subsection{Consideration Set Formation:}

Here I examine how households determine which brands to consider when they make their purchase decision. Children consider any brands of which they are aware. In the absence of advertising this is just the established brands they have heard of. If advertising is permitted, they also consider any brand (established or not) for which they have seen an ad. If a child has not heard of at least one established brand and has not seen any ads for any brands, the parent goes to the store and shops randomly on behalf of the child.

In every case the parent also considers the outside option. The outside option is the breakfast alternative (family cereal, oatmeal, croissant, etc.) that a parent might purchase if their child was not asking for specific children's brands. As a 
result, the outside alternative is assumed to be in every household's consideration set.

A comment is in order about the assumption that households consider randomly when they are not aware of any brands but do not consider anything other than an established brand if it is the only one they have heard of. This is basically a limited rationality assumption. If a parent is pestered by their child about a particular brand, they view this brand as being acceptable to their child. They compare this brand to the breakfast alternative they would select and buy whichever yields higher utility for their child. If a parent is not pestered by their child they will look around to see if there is some brand that their child might like and compare this to the outside alternative.

\subsection{Equilibrium Market Shares:}

In this subsection I study the market shares that result in a monopolistically competitive equilibrium. As described above, households purchase the brand that yields them the highest utility. Here, this utility comparison involves only those brands that enter the household's consideration set, and so the likelihood that a household purchases a particular brand depends on which other brands the household is aware of. That is, a brand's market share is a function of the probability that households are aware of it and of other brands. This probability depends on whether advertising is allowed or not. I describe demand in these two cases:

Case 1: Advertising is permitted

When advertising is allowed, households are aware of a brand if they have heard of it or if they have received an ad for it. So with probability $g_{j}+\left(1-g_{j}\right) a_{\widehat{j}}$ a given household is aware of brand $\widehat{j}$ (this is also the fraction of households that are aware of $\widehat{j}$ ). The household considers $\widehat{j}$, along with any other brand they are 
aware of. All brands that the household considers enter the denominator of (3). If there are $N_{e}$ established brands and $N_{n}$ non-established brands, then there are $z=2^{N_{e}+N_{n}-1}$ possible consideration sets, conditional on being aware of brand $\widehat{j}$. I define a household's $\widehat{j}$-conditional consideration set, $K_{z}^{\widehat{j}}$, to be the set of brands they are aware of conditional on being aware of brand $\widehat{j}$. A $K_{z}^{\hat{j}}$ set is of the form $K_{z}^{\widehat{j}}=\left[k_{z, 1}, \ldots, k_{z, \widehat{j}-1}, k_{z, \widehat{j}+1}, \ldots, k_{z, N_{e}+N_{n}}\right]$ where $k_{z, j}=\{0,1\}: 0$ if households are not aware brand $j$ and 1 if they are.

For example, if $N_{e}=3$ and $N_{n}=1$ and a household is aware of brand $e_{1}$, then their $e_{1}$-conditional consideration set is either $K_{1}^{e_{1}}=[1,0,0], K_{2}^{e_{1}}=[0,1,0]$, $K_{3}^{e_{1}}=[1,1,0], K_{4}^{e_{1}}=[0,0,0], K_{5}^{e_{1}}=[1,0,1], K_{6}^{e_{1}}=[0,1,1], K_{7}^{e_{1}}=[1,1,1]$ or $K_{8}^{e_{1}}=[0,0,1] . \quad K_{1}^{e_{1}}$ describes the case where a household is aware of $e_{2}$ but not $e_{3}$ or $n_{1}$. I define $h_{j}$ to be the probability that a household is aware of brand $j$. In the advertising-allowed case, $h_{j}=g_{j}+\left(1-g_{j}\right) a_{j}$. So the probability that a household's $e_{1}$-conditional consideration set is $K_{1}^{e_{1}}$ is $h_{e_{2}}\left(1-h_{e_{3}}\right)\left(1-h_{n_{1}}\right)$ or $\left[g_{e_{2}}+\right.$ $\left.\left(1-g_{e_{2}}\right) a_{e_{2}}\right]\left[\left(1-g_{e_{3}}\right)\left(1-a_{e_{3}}\right)\right]\left[\left(1-a_{n_{1}}\right)\right]$. The probabilities of each of the seven other conditional consideration sets can be determined in similar fashion. Conditional on being aware of $e_{1}$, with probability $\left[g_{e_{2}}+\left(1-g_{e_{2}}\right) a_{e_{2}}\right]\left[\left(1-g_{e_{3}}\right)\left(1-a_{e_{3}}\right)\right]\left[\left(1-a_{n_{1}}\right)\right]$ $e_{1}$ 's market share is:

$$
s_{e_{1}}(1)=\frac{\exp \left(v_{e_{1}}-p_{e_{1}}\right)}{1+\exp \left(v_{e_{1}}-p_{e_{1}}\right)+\exp \left(v_{e_{2}}-p_{e_{2}}\right)}
$$

The sum over these probability weighted shares yields what I will call $e_{1}$ 's conditional market share (the share of households who purchase $e_{1}$ conditional on being aware of $\left.e_{1}\right)$.

In general, the probability that a household's $\widehat{j}$-conditional consideration set is $K_{z}^{\widehat{j}}$ is:

$$
\Pi_{j \neq \hat{j}} h_{j}^{k_{z, j}}\left(1-h_{j}\right)^{1-k_{z, j}}
$$


So conditional on being aware of $\widehat{j}$, with probability (4) $\hat{j}$ 's share is:

$$
s_{\widehat{j}}(z)=\frac{\exp \left(v_{\hat{j}}-p_{\hat{j}}\right)}{1+\exp \left(v_{\hat{j}}-p_{\hat{j}}\right)+\sum_{m=1, m \neq \hat{j}}^{m=N_{e}+N_{n}}\left(k_{z, m} \exp \left(v_{m}-p_{m}\right)\right)}
$$

The sum over these probability weighted shares yields $\widehat{j}$ 's conditional market share:

$$
\sum_{z=1}^{2^{N_{e}+N_{n}-1}}\left(\Pi_{j \neq \hat{j}} h_{j}^{k_{z, j}}\left(1-h_{j}\right)^{1-k_{z, j}}\right) s_{\widehat{j}}(z)
$$

Households that are unaware of $\widehat{j}$ will not consider purchasing it unless they are unaware of any brands. In this situation households will go to the store and randomly choose a brand from the shelf and purchase it if it is preferred to the outside option. Market share for $\hat{j}$ in this situation is:

$$
\frac{1}{N_{e}+N_{n}} \frac{\exp \left(v_{j}-p_{j}\right)}{1+\exp \left(v_{\hat{j}}-p_{\hat{j}}\right)}
$$

Case 2: Advertising is not permitted

If advertising is not allowed, then only $\widehat{e}$-conditional consideration sets need to be defined since there is no way for a household to become aware of non-established brands. That is, $k_{z, n}=0$ for all $z$ and $n$, so there are only $z=2^{N_{e}-1} \widehat{e}$-conditional consideration sets. $\widehat{e}$ 's conditional market share is:

$$
\sum_{z=1}^{2^{N_{e}-1}}\left(\Pi_{j \neq \hat{e}} h_{j}^{k_{z, j}}\left(1-h_{j}\right)^{1-k_{z, j}}\right) s_{\widehat{e}}(z)
$$

where

$$
s_{\widehat{e}}(z)=\frac{\exp \left(v_{\widehat{e}}-p_{\widehat{e}}\right)}{1+\exp \left(v_{\widehat{e}}-p_{\widehat{e}}\right)+\sum_{m=1, m \neq \hat{e}}^{m=N_{e}}\left(k_{z, m} \exp \left(v_{m}-p_{m}\right)\right)}
$$

and where, in this case, $h_{j}=g_{j}$.

As in case 1 if a household is unaware of a brand $\widehat{e}$, they will not consider purchasing it unless they are unaware of any brands, in which case they will go to 
the store and randomly choose a brand from the shelf and purchase it if it is preferred to the outside option. This is also the situation faced by any non-established brand, $\widehat{n}$.

\subsection{Predictions:}

The theoretical model generates predictions about the market shares of established and non-established brands in markets where advertising is allowed versus in markets where it is prohibited. The first proposition states that if enough people have heard of the established brands, then they do better in markets where advertising is restricted. If most people have heard of an established brand, $\widehat{e}$, then, since advertising is strictly informative, it gains little market share from advertising. At the same time, if they are allowed to advertise, non-established brands become competition for $\widehat{e}$ by adding themselves to households' consideration sets.

Proposition 1. If a large fraction of the population has heard of brand $\widehat{e}$, then $\widehat{e}$ 's market share, $S_{\widehat{e}}$, is bigger in markets where advertising is prohibited

Proof. I show that at $g_{\widehat{e}}=1, S_{\widehat{e}}($ no $a d)>S_{\widehat{e}}\left(a_{\widehat{e}}^{*}\right)$, and since $g$ is continuous around 1 , the claim is true.

At $g_{\widehat{e}}=1$ all consumers are aware of brand $\widehat{e}$. If advertising is not allowed then demand for it is given by:

$$
S_{\widehat{e}}(\text { no } a d)=\sum_{z=1}^{2^{N_{e}-1}}\left(\Pi_{j \neq \widehat{e}} h_{j}^{k_{z, j}}\left(1-h_{j}\right)^{1-k_{z, j}}\right) s_{\widehat{e}}(z)
$$

and if it is allowed demand is given, by:

$$
S_{\widehat{e}}\left(a_{\widehat{e}}^{*}\right)=\sum_{z=1}^{2^{N_{e}+N_{n}-1}}\left(\Pi_{j \neq j} h_{j}^{k_{z, j}}\left(1-h_{j}\right)^{1-k_{z, j}}\right) s_{\widehat{j}}(z)
$$




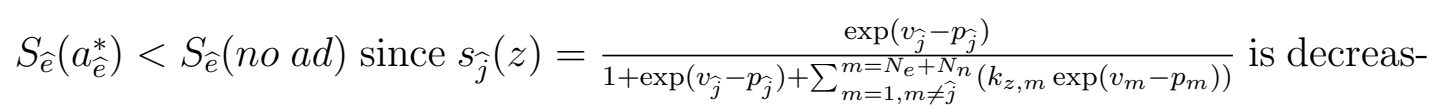
ing in each of the $k_{z, j}$. That is, the more other brands a consumer is aware of, the smaller will be demand for $\widehat{e}$. $k_{z, j}=1$ with probability $h_{j}$ which is bigger when advertising is allowed. $\quad h_{e}$ is equal to $g_{e}$ when advertising is not allowed and to $g_{e}+\left(1-g_{e}\right) a_{e} \geq g_{e}$ when it is. $h_{n}$ is equal to 0 when advertising is not allowed and to $a_{n} \geq 0$ when it is.

The second proposition states that if enough people have heard of at least one established brand, then non-established brands do better in markets where advertising is permitted. If advertising is not allowed, only those people who have not heard of the established brand consider any non-established brands-so their market share will be small.

Proposition 2. If a large fraction of the population has heard of at least one established brand, then market share for a non-established brand $\widehat{n}$ is bigger in markets where advertising is allowed

Proof. If $g_{e}=1$ for any brand $e$, then market share for any non-established brand is 0 if advertising is not allowed.

Both of these propositions are shown for $g_{e}$ 's in the neighborhood of one. In the context of the breakfast cereal market, $g_{e}$ near one implies that most people in the population have heard of an established breakfast cereal. Harris Interactive, a market research firm, constructs a brand equity measurement tool that ranks over one thousand different brands according to their equity (measured in terms of salience and quality). A number of cereals make the list of top one thousand brands suggesting that it is reasonable to assume that a large fraction of the population have heard of established cereal brands. 


\section{Data}

In order to estimate the model, the following variables are necessary: market shares, prices, brand characteristics, and advertising expenditures.

The market shares are calculated using Category Reports from the Print Measurement Bureau. Each year the PMB surveys approximately 15000 Canadian households. The PMB study design includes weighting to match Statistics Canada household and individual population data. There are two weighting processes: (i) design weights that compensate for over or under sampling, (ii) projection to match the population estimates of Statistics Canada. Questionnaires are left behind by interviewers and contain questions about the household's product usage. Respondents are asked to report on the brands of cold cereal used in their household in the previous year. PMB reports in its survey on the number of households that used a brand at least once. So a brand's market share represents its fraction of cereal use as opposed to its fraction of cereal purchases, and as a result lacks any notion of intensity of usage.

I have four years of PMB reports, 1998-2001. Each year's PMB report provides results from a survey taken in the previous year (so my data cover 1997-2000). Usage is reported for six Canadian regions: Atlantic Canada, Quebec, Ontario, Manitoba/Saskatchewan, Alberta and British Columbia. For 1997, 55 cereals are reported on, out of which 15 are children's brands. For 1998, 17 out of 57 are children's brands. For 1999, 17 out of 67 are children's brands. For 2000, 17 out of 74 are children's brands. My classification of breakfast cereals into children's cereals and non-children's cereals is based on classifications by Nevo and Shum. (See table 1 in the appendix for a list of which children's brands were reported on each year).

The price data are collected by AC Nielsen. ${ }^{6}$ I have prices for each brand in

\footnotetext{
${ }^{6}$ These data were used for academic purposes only and the results obtained do not necessarily
} 
each of the four years in each of the six regions. They are calculated using samples or aggregate census data for grocery supermarket banners as follows: total revenue from boxes of all sizes divided by total quantity. This measure is not ideal as it does not represent a properly weighted average. I can construct a somewhat better measure of price for 1999 and 2000 since I have information on the average price per box of different sizes. For each brand I choose the box size closest to 400 grams and I calculate the average price per 100 grams. I test the effect of using these prices on results.

Brand characteristics come from the Nutrient Database for Standard Reference compiled by the Agricultural Research Service of the United States Department of Agriculture. Nevo (2000) includes total calories, dietary fiber and sodium as characteristics in his breakfast cereals study. I include fiber and sodium along with sugar rather than calories. Sugar and fiber are measured in grams per 100 gram serving, while sodium is measured in milligrams per 100 gram serving. Brand characteristics do not vary over time or across regions.

Advertising data come from the AC Nielsen Media Services annual estimates of Advertising Expenditures in Canada. Annual national advertising expenditure is reported for each brand. Only advertising spending that originates in Canada is included, anything spilling over from the United States is omitted. The data are collected through the following sources: television, radio, daily newspapers, magazines and out-of-home. Almost all of the advertising for ready-to-eat breakfast cereals is done through the television. The following networks are included in AC Nielsen's estimates: TVA, Radio Canada, TQS, CBC, CTV, BBS Ontario, Global, MITV, TSN, Musique Plus, MuchMusic and Newsworld.

See table 2 in the appendix for summary statistics.

reflect the views of AC Nielsen. 


\section{Empirical Specification}

In this section I describe the empirical specification that will be used to test the predictions from the theoretical model of informative advertising using the data described above. The main predictions are that market shares for established brands should be higher in regions where advertising is restricted than in regions where it is permitted and that the opposite should be true for non-established brands. I take advantage of the fact that advertising is prohibited in Quebec to test whether market shares for established brands are higher in Quebec than in the rest of Canada and whether market shares for non-established brands are lower.

What does it mean for a brand to be established? As described in the theoretical model, established brands, unlike non-established brands, are recognized even in the absence of current advertising. So my classification of brands must capture the fact that consumers are aware of established brands even if they do not see ads for them during the purchasing period. One possible classification involves denoting a brand established if it has been around for a long time. But since longevity does not necessarily imply recognition, this is not enough. There exist brands that have been around for some time, but that have little brand equity and regularly very low market share (for instance Post Pebbles). So the classification must involve some indication of the manner in which awareness is generated. Therefore, I classify brands as established if they have been around for a long time and if they regularly engage in heavy promotional activity. I do not have data on all of the types of promotion that firms have engaged in and so attempt to capture a brand's typical promotional activity by its recent expenditure on advertising. I denote a brand established if it has been around since at least 1983 and it has spent more than two hundred thousand dollars on advertising nationally in at least two of the four years 
of the sample. ${ }^{7}$ Although somewhat ad hoc, I think that this definition captures the essence of what it means to be established. Even in Quebec where advertising is banned, recent national advertising expenditure should proxy for recent unrestricted promotional activity and for past advertising.

In section 5.1 below I test the robustness of my results to the definition of established. I present results from two other possible classifications. Definition 2 maintains the importance of heavy promotional activity. Brands are established if they have been around since at least 1983 and if they have spent a minimum of two hundred thousand dollars on national advertising in each of the two previous years. Definition 3 examines how important heavy promotional activity is to being established and classifies a brand as established simply if it has been around for a long time. So brands are established if they have been around since at least 1983 .

In addition to depending on whether or not it is established, a brand's market share is influenced by its price, its expenditure on advertising and its characteristics. I include annual national brand-specific advertising expenditure as my advertising variable. National expenditure allows me to capture the variation in advertising intensity from one cereal brand to another. Although the actual amount of advertising that is viewed by individuals in different provinces may vary in magnitude, the brand variation should be roughly similar and so units should not matter. In using this as my advertising variable I am allowing for the fact that despite the ban there is some spillover of advertising into Quebec. ${ }^{8}$ The amount of advertising that spills over into Quebec is some fraction of the national amount. As long as it spills over in the same way for all of the brands in the sample, then it does not matter

\footnotetext{
${ }^{7} 1983$ is as far back as I could find information on brand introduction.

${ }^{8}$ In 1992, advertising expenditures on children's breakfast cereal in Quebec were $\$ 1.3$ million (Caron (1995)). This represents $14.6 \%$ of the total spent in Canada (Quebec expenditures on all types of cereals represented $20.2 \%$ of the Canadian total).
} 
what the actual amount spilling over is.

To examine the market share outcomes of established and non-established brands in Quebec, I construct an indicator variable for this province in order to capture the effect of the advertising restriction. For this approach to be valid, consumption patterns in Quebec and the rest of Canada must be similar in the absence of advertising restrictions. In other words, the Quebec variable must only capture the effect of the ban and not other factors which are specific to Quebec. In its Window on Quebec 2001, AC Nielsen reports that consumers in Quebec are similar to their counterparts in the rest of Canada in many regards. Most importantly, they do not seem to be more brand loyal in Quebec than in the rest of Canada on average. Using its Homescan Consumer Panel AC Nielsen measures ongoing product acceptance and retention. It seems that Quebec consumers are no less likely to spread their purchases in a product category across brands. Were this not the case, then it could be argued that a result that indicated that established cereal brands do better in Quebec is caused by the fact that Quebec consumers are more brand loyal in general. In addition, the Window on Quebec reports that people in Quebec watch approximately the same amount of television (22.5 hours per week in Quebec vs. 21.5 hours per week in Canada) and spend approximately the same amount on food (\$114.9 per week in Quebec vs. $\$ 112.09$ per week in Canada) and on baked goods/cereals in particular (\$13.42 per week in Quebec vs. $\$ 12.47$ per week in Canada). Moreover Quebec consumers do not have a bias against presweetened cereals. The Print Measurement Bureau data show that in 1999, twenty-five per cent of cereal usage in Quebec was of presweetened cereals, versus twenty-six percent nationally. The Print Measurement Bureau also reports that the fraction of households in Quebec with children under the age of twelve is not much different than in Canada as a whole (in 2000, 25.5\% in Quebec vs. 27\% nationally). 
Likely the biggest difference between Quebec and the rest of Canada is in terms of language. Only $43 \%$ of the population of Quebec can speak English (defined by Statistics Canada as being able to carry on a conversation, 1996 Census). Given this, one possible interpretation of any result suggesting that established brands have bigger market share in Quebec is that people that speak only French have a preference for established brands. National advertising, if it is mostly in English, would have little effect on people that speak only French and they would simply purchase brands that had been around for a long time because those are the ones they have heard of. This would be particularly problematic if established only meant old. However, I have defined established brands to be those that have been around for a long time and that advertise nationally regularly. Therefore, a result suggesting that established brands have bigger market share in Quebec implies that regular national advertising does have an effect on French speaking people. Moreover, although Statistics Canada reports that such a small fraction of the population are able to speak in English this does not mean that a much larger fraction understand enough English to make sense of breakfast cereal commercials. Children in Quebec begin learning English in Grade 3 (Grade 4 prior to 1999).

I regress observed market share of each of the brands on price, national advertising, brand characteristics (sugar, fiber and sodium), and the established indicator. ${ }^{9}$

\footnotetext{
${ }^{9} \mathrm{~A}$ logit model of demand in which advertising simply appears in the utility function would yield a different dependent variable-the difference between the log of each brand's observed share and the log of the share of the outside alternative. Although the specification I have suggested is not derived structurally from the model, is does stem directly from the predictions that arise. In order to use $\ln \left(S_{j r t}\right)-\ln \left(S_{o}\right)$ as the dependent variable the theoretical model must say something about the relationship between market shares for children's cereals and the share of the outside good. Although the model can predict that the share of the outside good is higher in markets where advertising is restricted, it cannot make predictions about relative share without making assumptions about the relative valuations of consumers for the different products.
}

That having been said, the main results do not change if $\ln \left(S_{j r t}\right)-\ln \left(S_{o}\right)$ is used as the dependent 
To test the predictions of the theoretical model I include an interaction between established and the Quebec indicator, Established*Quebec, and an interaction between non-established and the Quebec indicator, Non-established*Quebec. A positive coefficient on the Established $*$ Quebec interaction term and a negative coefficient on the Non-established $*$ Quebec interaction term would indicate that the ban helps established brands and hurts non-established brands. More specifically, I estimate the following reduced form equation:

$$
\text { Share }_{j r t}=\beta_{0}+\beta_{1} p_{j r t}+\beta_{2} a_{j t}+\beta_{3} x_{j}+\beta_{4} E_{j t}+\beta_{5} * Q * E_{j}+\beta_{6} * Q * N E_{j}+\varepsilon_{j r t}
$$

where Share $_{j r t}$ is brand $j$ 's share in region $r$ in year $t, p_{j r t}$ is brand $j$ 's price in region $r$ in year $t, a_{j t}$ is brand $j$ 's national advertising expenditure in year $t$ and $x_{j}$ is a vector of observed characteristics for brand $j . \quad Q$ is an indicator that equals 1 if the region is Quebec while $E_{j}$ is an indicator that equals 1 if brand $j$ is considered established and $N E_{j}$ is an indicator that equals 1 if brand $j$ is considered non-established. The primary parameters of interest are $\beta_{5}$ and $\beta_{6}$, which are intended to capture the effects of being established and non-established in Quebec relative to (being established and non-established in) the rest of Canada respectively. Regressions will also include year dummies to control for any systematic shocks to demand.

\section{Estimation Results}

Before estimating (10) it is important to account for the possibility that $\varepsilon_{j r t}$ is correlated with certain explanatory variables. Failure to do so could result in biased and inconsistent estimates. Endogeneity bias may exist if unobserved determinants of a brand's market share also affect its price or advertising expenditure. For instance, unobservable promotional activity such as in-store displays and sponsorships variable. 
of sporting/schooling events could affect market shares directly but also influence prices and expenditures on traditional means of advertising. Systematic shocks to demand such as those generated by health warnings (announcements about the increasing obesity of children) can also affect market share as well as advertising and pricing strategies. Furthermore, brand equity might further compromise the exogeneity of the price and advertising expenditure variables.

In an attempt to deal with this issue I start by adding firm dummies to the model. There are clearly unobservables at the firm level that affect market share directly as well as advertising budgets. In other words, firms have general marketing strategies that they apply to all of their brands. For instance Kelloggs may decide to pay for premium shelf space at the super market for its brands. This might increase market share directly and could be part of an overall promotional strategy that sees the firm spending more on television advertising as well. Results from the estimation of (10) with firm dummies are reported in table 3. Mean market share in the sample is .015. If price increases by one dollar, market share falls by .0047. An extra million dollars spent on advertising improves market share by .0034, while being established improves market share by .013. These coefficients are all significant at the 5\% level. Being established in Quebec increases market share relative to being established in the rest of Canada by .0032 (significant at the $10 \%$ level), while the effect of being non-established in Quebec is not significantly different from zero.

However, controlling for firm specific unobservables is not enough to resolve all endogeneity problems. While firm dummies should control for any unobserved heterogeneity stemming from the manufacturer that affects a brand's market share and that influences its price and the amount spent promoting it, there is also brandspecific unobserved heterogeneity. To deal with this I adopt a fixed effects model. 
Results from the fixed effects estimation are reported in table 4 under the heading $\mathrm{FE}(1)$. Including fixed effects means that the firm dummies, the Established variable and the observed characteristics that make up $x_{j}$ are dropped from the model since they do not vary from one market to another. However I can still estimate my coefficients of interest since they do vary across markets. Being established in Quebec increases market share relative to being established in the rest of Canada by .0032, while being non-established in Quebec reduces market share relative to non-established brands in the rest of Canada by .0014. These coefficients are both significant at the $5 \%$ level. Also an increase in price of one dollar reduces market share by .0021 (significant at the 5\% level) and a one million dollar increase in advertising expenditure improves market share by .0012 (significant at the $10 \%$ level).

As noted in Nevo (2000), once brand effects are included, the error term is the unobserved region-year deviation from the overall mean valuation of the brand. Firms are assumed to be able to observe this deviation and account for it when choosing their marketing strategies. While advertising strategies may be determined at the firm level or the brand level, it seems likely that when setting their prices in each market (region-year) firms take the deviation from the mean valuation into account. To deal with this, I adopt and instrumental variables approach. A common set of instruments employed to deal with the endogeneity of price in discrete choice models (Nevo (2000), Rekkas(2001), Berry, Levinsohn and Pakes(1995)) includes the observed brand characteristics, the sums of the values of the same characteristics of other brands sold by that firm, and the sums of the values of the same characteristics of the brands offered by other firms. These variables are meant to proxy for the closeness of the competition in the market. I do not adopt this approach here since in my case there is almost no variation between markets in these instruments. This 
is because there is little variation over time and no variation across regions in the brands available for sale in my data and so this amounts to little more than adding brand dummies.

Another approach used by Nevo (2000) to deal with the potential endogeneity of price in his breakfast cereal study, is an instrumental variable method proposed by Hausman. This method relies on the assumption that region-specific valuations of brands are independent across regions controlling for brand-specific intercepts. So prices of a brand in other regions are valid instruments. This is because prices of a particular brand in two regions are correlated due to the common marginal cost of producing the brand but uncorrelated with the market-specific valuation of the brand. Therefore, as an instrument I use regional yearly average prices (not including the region being instrumented) in all four years. The assumption that valuations are independent across regions will not hold in a number of circumstances. For instance if there is some national shock then all regions will be affected. The inclusion of time dummies should help to alleviate this concern. Also if local advertising or in-store promotions are correlated across regions, then the independence assumption will be violated. Nevo points out that the larger the regions, the less likely it is that there will be correlation across borders. In my case regions are entire Canadian provinces (or multiple provinces in the cases of Manitoba/Saskatchewan and Atlantic Canada) and it is therefore doubtful that in-store promotional strategies are coordinated across such vast distances.

Results from the fixed effects model with the instrument for price are reported in table 5 under the heading FIV(1). The coefficient on price is -.007 and the coefficient on advertising is .0016 and both are significant at the $5 \%$ level. The coefficients on Established*Quebec and Non-established*Quebec are .0032 and -.0016 respectively, and both are significant at the $5 \%$ level. 
These results suggest that the predictions of the theoretical model are supported by the data. Established brands have higher market shares in regions where advertising is restricted and the opposite is true for non-established brands. These results lend support to the pro-competitive view of advertising. If advertising is pro-competitive, it should help to overcome brand loyalty by providing a means for new and less established brands to pass on information about their existence or characteristics. Restricting advertising in this case prevents these brands from competing with those that are already established. The lower market shares for the non-established brands in Quebec suggest that this may be what is in fact occurring. Without the ability to advertise, new, less established brands are at a competitive disadvantage relative to established brands.

\subsection{Robustness:}

I first test the robustness of my results to the way in which brands are classified as established or non-established. As mentioned above, I test two other definitions. Definition 2 classifies a brand as established if it has been around since at least 1983 and has spent a minimum of two hundred thousand dollars on national advertising in the two previous years. Under this definition brands can switch from being established to not over the four year sample (although only one, General Mills Golden Grahams, actually does). Definition 3 considers a brand established if it has been around for a long time-at least since 1983.

The classification due to Definition 2 is not very different from the one due to the main definition of established and results are essentially unchanged. Results are reported in table $4(\mathrm{FE}(2))$, and table $5(\mathrm{FIV}(2))$. Established is no longer dropped

in the fixed effects model since a brand's classification can change from year to 
year. However its effect on market share is not significantly different from zero. Being established in Quebec increases market share relative to being established in the rest of Canada by .0029, while being non-established in Quebec reduces market share relative to non-established brands in the rest of Canada by .0014. These coefficients are significant at the $5 \%$ level. Results from the fixed effects instrumental variables regression show that the coefficients on Established $*$ Quebec and Non-established $*$ Quebec are .0032 and -.0016 respectively, and both are significant at the $5 \%$ level.

The classification generated by Definition 3 is quite different than the ones generated by Definitions 1 and 2. Results are reported in tables 4, and 5 under the headings $\mathrm{FE}(3)$ and $\mathrm{FIV}(3)$ respectively. In the fixed effects model, the coefficient on Established $*$ Quebec is .0013 and is significant at the $5 \%$ level and the coefficient on Non-established $*$ Quebec is -.0015 and is just barely significant at the $10 \%$ level. Results from the fixed effects instrumental variables regression show that the coefficient on Established $*$ Quebec is .0012 (significant at the $10 \%$ level) while the coefficient on Non-established $*$ Quebec is not significantly different from zero.

I also test the robustness of my results to the quality of my price data. I run the same specifications using just the final two years of data. For these two years I have price data that represent a properly constructed weighted average. In the fixed effects model increasing price by one dollar per hundred grams causes market share to fall by .0084 and is significant at the 5\% level. Being established in Quebec increases market share by .0026 (significant at the 5\% level). Once price is instrumented for as well the coefficient on price is no longer significantly different from zero. The coefficient on Established*Quebec is .0027 and is significant at the $5 \%$ level. Both with and without the instrument for price, the coefficient on Non-established $*$ Quebec is no longer significantly different from zero. 
In the two year sample, definition 2 yields the same classification of brands as Definition 1. Using Definition 3, neither Established*Quebec or Non-established*Quebec are significant (table $4 \mathrm{FE}(5)$, table $5 \mathrm{FIV}(5)$ ).

Brands that are old and have engaged in heavy promotional activity do better in Quebec than in the rest of the country. In the four year sample, this result holds even for brands that are simply old. For the two year sample the effect of being old in Quebec is not significantly different from zero. For these two years of the sample more accurate price data are available. More accurate data mean less measurement error. However this comes at a cost, since these data are only available for 1999 and 2000. This smaller sample means less variation and so is bad from an efficiency stand point. There is also no significant effect from being new in the two year sample and in the full sample the effect is only significant at the $10 \%$ level (fixed effects model without the price instrument).

The two definitions that classify a brand as established if it has been around for some time and heavily engages in promotion lead to similar results, and suggest that established brands, by virtue of the fact that they are recognizable, do better when advertising is prohibited. There is evidence that just being old is important, but it is not conclusive that in the absence of current advertising old brands do better and new brands do worse.

\section{Conclusions}

In this paper I have examined the possibility that an unintended consequence of the ban on advertising directed at children in Quebec is to hinder competition. I construct a theoretical model of informative advertising that predicts that older, betterknown brands have bigger market share in regions where advertising is prohibited 
than in regions where it is allowed, and that the opposite is true for non-established brands.

Empirical analysis of the children's breakfast cereal market supports these predictions. Established brands-those that have been around for a long time and that advertise regularly-have bigger market share in the province of Quebec where advertising is banned than they do in the rest of Canada. Non-established brand do better in the rest of Canada.

To the extent that informative advertising can be viewed as pro-competitive, this paper has demonstrated that restricting advertising may hinder competition. New, less established brands are unable to inform consumers about their existence and as a result find themselves at a competitive disadvantage relative to established brands in Quebec.

\section{$7 \quad$ References}

AckerberG, D. (2002): "Empirically Distinguishing Between Informative and Prestige Effects of Advertising," Rand Journal of Economics, 33, 316-333.

—_- (1998): "Advertising, Learning, and Consumer Choice in Experience Good Markets: A Structural Empirical Examination," Boston University, mimeo.

AC Nielsen Company of Canada (1995-2000): Market Track-Grocery Banner.

- (2001): Window on Québec.

ADAge website: www.adage.com.

Advertising Education Forum website: www.aeforum.org. 
Anand, B., And Shacher, R. (2001): "Advertising, the Matchmaker," Harvard Business School Working Paper 02-057.

Anderson, S., de Palma, A., And Thisse, J.-F. (1992): Discrete Choice Theory of Product Differentiation, The M.I.T. Press, Cambridge, MA.

Baltagi, B. (1995): Econometric Analysis of Panel Data, John Wiley \& Sons, New York, NY.

Benham, L. (1972): "The Effect of Advertising on the Price of Eyeglasses," Journal of Law and Economics, 15, 337-352.

Berry, S., And Levinsohn, J., And Pakes, A. (1995): "Automobile Prices in Market Equilibrium," Econometrica, 63, 841-890.

Besanko, D., Perry, M., And Spady, R. (1990): "The Logit Model of Monopolistic Competition: Brand Diversity," Journal of Industrial Economics, 38, 397-415.

Brown-Humes, C. (2001): "Creative Business: Advertising and Children," Financial Times.

Butters, G. (1977): "Equilibrium Distributions of Sales and Advertising Prices," The Review of Economic Studies, 44, 465-491.

Caron, A. And Martin, C. (1995) Les impacts de la réglementation québécoise de la publicité destinée aux enfants sur les ventes de temps et d'espace publicitaires, Laboratoire d'économie industrielle des médias et Groupe de recherche sur les jeunes et les médias, Université de Montréal, Montréal, PQ.

ECKARD, W. JR. (1991): "Competition and the Cigarette TV Advertising Ban," Economic Inquiry, 29, 119-133. 
Gale Research Group: Companies and their Brands.

Grossman, G., And Shapiro, C. (1984): "Informative Advertising with Differentiated Products," The Review of Economic Studies, 51, 63-81.

Goeree, M. (2002): "Advertising in the U.S. Personal Computer industry", University of Virginia, mimeo.

HARRIS INTERACTIVE (2001): Equitrend.

Holak, S., And RedDy, S. (1986): "Effects of a Television and Radio Advertising Ban: A Study of the Cigarette Industry," Journal of Marketing, 50, 219-227.

Jordan, A. (1996): The State of Children's Television: An Examination of Quantity, Quality, and Industry Beliefs [Report No. 2], Annenberg Public Policy Center, University of Pennsylvania, Philadelphia, PA.

Kessides, I. (1986): "Advertising, Sunk Costs, and Barriers to Entry," The Review of Economic Studies, 68, 84-95.

Nevo, A. (2001): "Measuring Market Power in the Ready-to-Eat Cereal Industry," Econometrica, 69, 307-342.

__- (2000): “A Practitioner's Guide to Estimation of Random-Coefficients Logit Models of Demand," Journal of Economics and Management Strategy, 9, 513-548. - (2000): "Mergers with Differentiated Products: The Case of the Ready-toEat Cereal Industry," RAND Journal of Economics, 31, 395-421.

Nielsen Media Services (1995-2001): Annual Summary of Advertising Expenditures in Canada, Nielsen Marketing Research, Markham, ON. 
Petrin, A. (2001): "Quantifying the Benefits of New Products: The Case of the Minivan", University of Michigan, mimeo.

Print Measurement Bureau (1997-2001): PMB Category Reports.

REKKAs, M. (2001): "Estimation of a Structural Model of Multiparty Elections: Canadian Evidence", University of Toronto, mimeo.

Sass, T., And Saurman, D. (1995): “Advertising Restrictions and Concentration: The Case of Malt Beverages," The Review of Economics and Statistics, 77, 66-81.

Shum, M. (2000): "Does Advertising Overcome Brand Loyalty? Evidence from the Breakfast Cereals Market", Johns Hopkins University, mimeo.

United States Department of Agriculture USDA Nutrient Database for Standard Reference, Release 14. Nutrient Data Laboratory.

Woodard, E. (1999): The 1999 State of Children's Television Report: Programming for Children Over Broadcast and Cable Television [Report No. 28], Annenberg Public Policy Center, University of Pennsylvania, Philadelphia, PA.

Wooldridge, J. (2002): Econometric Analysis of Cross Section and Panel Data, The M.I.T. Press, Cambridge, MA. 


\section{Appendix:}

Table 1:

\begin{tabular}{|l|l|l|l|}
\hline Brands & $\begin{array}{l}\text { in } \\
\text { PMB 98 }\end{array}$ & $\begin{array}{l}\text { existed } \\
\text { in 1983 }\end{array}$ & $\begin{array}{l}\text { advertised in at } \\
\text { least 2 of 4 years } \\
\text { i \$200 000) }\end{array}$ \\
\hline GM Cinnamon Toast Crunch & y & n & y \\
\hline GM Count Chocula & y & y & n \\
\hline GM French Toast Crunch & n & n & y \\
\hline GM Golden Grahams & y & y & n \\
\hline GM Lucky Charms & y & y & y \\
\hline GM Nesquick & n & n & y \\
\hline GM Reese's Puffs & y & n & n \\
\hline GM Trix & y & y & n \\
\hline Kellogg's Cinnamon Mini Buns & y & n & n \\
\hline Kellogg's Corn Pops & y & y & y \\
\hline Kellogg's Froot Loops & y & y & y \\
\hline Kellogg's Frosted Flakes & y & y & y \\
\hline Post Alphabits & y & y & y \\
\hline Post Honeycombs & y & y & y \\
\hline Post Pebbles & y & y & n \\
\hline Post Sugar Crisp & y & y & y \\
\hline Quaker Cap'n Crunch & y & y & n \\
\hline
\end{tabular}


Table 2:

Summary statistics for children's breakfast cereals.

\begin{tabular}{lllll}
\hline & Min & Max & Mean & St.Dev \\
\hline \hline Share in market $(\%)$ & .000067 & .054 & .015 & .012 \\
Share in market $(\%) ' 99,{ }^{\circ} 00$ & .000067 & .0488 & .0148 & .012 \\
Advertising ( $\$$ millions per year) & 0 & 3.11 & .499 & .574 \\
Advertising '99, 00 & 0 & 1.484 & .397 & .416 \\
Price (\$ per box) & 2.06 & 5.59 & 3.769 & .507 \\
Price (\$ per 100g in '99, $\left.{ }^{\circ} 00\right)$ & .458 & 1.242 & .859 & .115 \\
Sugar (grams per 100g) & 35.47 & 53.9 & 41.31 & 4.37 \\
Sodium (milligrams per 100g) & 150 & 915 & 588.7 & 183.1 \\
Fiber (grams per 100g) & .7 & 5 & 2.51 & 1.09 \\
\hline
\end{tabular}


Table 3:

Results from estimation of (10) with firm dummies :

\# of observations: 396

\begin{tabular}{lc}
\hline \multicolumn{1}{c}{ Coef. } \\
\hline \hline Price & $-.0047^{* *}$ \\
& $(.0016$ \\
Advertising & $.0034^{* *}$ \\
& $(.0015)$ \\
Established & $.013^{* *}$ \\
& $(.0033$ \\
Established*Quebec & $.0032^{*}$ \\
& $(.0018)$ \\
Non-established ${ }^{*}$ Quebec & -.0015 \\
& $(.0011)$ \\
\hline robust standard errors are reported in parentheses $)$ \\
(* coefficient significant at $10 \%$ level; $* *$ coefficient significant at $5 \%$ level)
\end{tabular}


Table 4:

Results from fixed effects estimation of (10):

\# of observations: $396 \mathrm{FE}(1), \mathrm{FE}(2), \mathrm{FE}(3)-4$ years

\# of observations: $204 \mathrm{FE}(4), \mathrm{FE}(5)-1999$ and 2000

in $\mathrm{FE}(1), \mathrm{FE}(4)$ : Established Def 1

in $\mathrm{FE}(2)$ : Established Def 2

in $\mathrm{FE}(3), \mathrm{FE}(5)$ : Established Def 3

Established Def 1 and 2 yield the same resulst for 2 year data $(\mathrm{FE}(4))$

\begin{tabular}{|c|c|c|c|c|c|}
\hline & $\mathrm{FE}(1)$ & $\mathrm{FE}(2)$ & $\mathrm{FE}(3)$ & $\mathrm{FE}(4)$ & $\mathrm{FE}(5)$ \\
\hline & Coef. & Coef. & Coef. & Coef. & Coef. \\
\hline \multirow{2}{*}{ Price } & $-.0021^{* *}$ & $-.0021^{* *}$ & $-.0020^{* *}$ & $-.0084^{* *}$ & $-.0082^{* *}$ \\
\hline & $(.0005)$ & $(.0005)$ & $(.0005)$ & $(.0038)$ & $(.0039)$ \\
\hline \multirow{2}{*}{ Advertising } & $.0012^{*}$ & $.0012^{*}$ & $.0012^{*}$ & .0027 & .0027 \\
\hline & $(.00069)$ & $(.00069)$ & $(.0007)$ & $(.0022)$ & $(.0022)$ \\
\hline \multirow{2}{*}{ Established } & & -.0001 & & & \\
\hline & & $(.0014)$ & & & \\
\hline \multirow{2}{*}{ Est*Qu } & $.0032^{* *}$ & $.0029^{* *}$ & $.0013^{* *}$ & $.0026^{* *}$ & .0011 \\
\hline & $(.0007)$ & $(.0007)$ & $(.00057)$ & $(.0011)$ & $(.0008)$ \\
\hline \multirow{2}{*}{ Nonest ${ }^{*} \mathrm{Qu}$} & $-.0014^{* *}$ & $-.0014^{* *}$ & $-.0015^{*}$ & -.0011 & -.0012 \\
\hline & $(.0006)$ & $(.0006)$ & $(.0009)$ & $(.0009)$ & $(.0013)$ \\
\hline
\end{tabular}

(*coefficient significant at $10 \%$ level; ${ }^{* *}$ coefficient significant at $5 \%$ level $)$ 


\section{Table 5:}

Results from fixed effects estimation with price IV of (10) : \# of observations: 396 FIV(1), FIV(2), FIV(3)-4 years \# of observations: 204 FIV(4), FIV(5)-1999 and 2000 in $\operatorname{FIV}(1), F I V(4)$ : Established Def 1 in $\operatorname{FIV}(2)$ : Established Def 2 in $\operatorname{FIV}(3), \operatorname{FIV}(5)$ : Established Def 3

Established Def 1 and 2 yield the same resulst for 2 year data (FIV(4))

\begin{tabular}{|c|c|c|c|c|c|}
\hline & FIV (1) & $\operatorname{FIV}(2)$ & $\operatorname{FIV}(3)$ & FIV (4) & FIV (5) \\
\hline & Coef. & Coef. & Coef. & Coef. & Coef. \\
\hline \multirow{2}{*}{ Price } & $-.007^{* *}$ & $-.007^{* *}$ & $-.007^{* *}$ & -.011 & -.0011 \\
\hline & $(.0026)$ & $(.0026$ & $(.0026)$ & $(.009)$ & $(.009)$ \\
\hline \multirow{2}{*}{ Advertising } & $.0016^{* *}$ & $.0016^{* *}$ & .0016 & .0027 & .0027 \\
\hline & $(.0008)$ & $(.0008)$ & $(.0008)$ & $(.0022)$ & $(.0022)$ \\
\hline \multirow{2}{*}{ Established } & & -.0005 & & & \\
\hline & & $(.002)$ & & & \\
\hline \multirow{2}{*}{ Est*Qu } & $.0032^{* *}$ & $.0028^{* *}$ & $.0012^{*}$ & $.0027^{* *}$ & .0011 \\
\hline & $(.0008)$ & $(.0008)$ & $(.0006)$ & $(.001)$ & $(.0008)$ \\
\hline \multirow{2}{*}{ Nonest* ${ }^{*} \mathrm{u}$} & $-.0016^{* *}$ & $-.0015^{* *}$ & -.0015 & -.0011 & -.0012 \\
\hline & $(.0007)$ & $(.0007)$ & $(.001)$ & $(.0009)$ & $(.0013)$ \\
\hline
\end{tabular}

${ }^{*}$ coefficient significant at $10 \%$ level; ${ }^{* *}$ coefficient significant at $5 \%$ level $)$ 